\title{
Denaturation of DNA in Ternary Mixed Solution of Water/Hydrophilic/Hydrophobic Organic Solvent
}

\author{
Yuki Ito ${ }^{1}$, Kazuhiko Tsukagoshi ${ }^{1,2}{ }^{*}$, Akira Kobayashi ${ }^{3}$ \\ ${ }^{1}$ Department of Chemical Engineering and Materials Science, Doshisha University, Kyotanabe, Japan \\ ${ }^{2}$ Bio-Microfluidic Science Research Center, Doshisha University, Kyotanabe, Japan \\ ${ }^{3}$ Department of Medical Life Systems, Doshisha University, Kyotanabe, Japan \\ Email: ${ }^{* k t s u k a g o @ m a i l . d o s h i s h a . a c . j p ~}$
}

How to cite this paper: Ito, Y., Tsukagoshi, K. and Kobayashi, A. (2017) Denaturation of DNA in Ternary Mixed Solution of Water/Hydrophilic/Hydrophobic Organic Solvent. Journal of Analytical Sciences, Methods and Instrumentation, 7, 40-46. https://doi.org/10.4236/jasmi.2017.72004

Received: April 17, 2017

Accepted: June 10, 2017

Published: June 13, 2017

Copyright (C) 2017 by authors and Scientific Research Publishing Inc. This work is licensed under the Creative Commons Attribution International License (CC BY 4.0).

http://creativecommons.org/licenses/by/4.0/

\begin{abstract}
Denaturation was examined for the first time in a ternary mixed solution of water/hydrophilic/hydrophobic organic solvent using $\lambda$-DNA and a plasmid as models. The absorbance of $\lambda$-DNA and the plasmid at $260 \mathrm{~nm}$ gradually increased for several days up to 1.68 and 1.38 times the initial values, respectively, in a water/acetonitrile/ethyl acetate (15:3:2, volume ratio) mixed solution, whereas there was little change in a water/acetonitrile (15:3, volume ratio) mixed solution. The plasmid treated with the ternary mixed solution was also examined with agarose gel electrophoresis. These experimental data indicated that $\lambda$-DNA changed from a double helix structure to a single helix structure and that the plasmid partially transformed to generate a denaturation bubble in the structure. The new idea of using the ternary mixed solution first enabled the interaction of the hydrophobic organic solvent (e.g., ethyl acetate) molecule with the double helical structure of DNA, leading to specific slow-proceeding denaturation.
\end{abstract}

\section{Keywords}

Denaturation, DNA, Ternary Mixed Solvent, Hydrophobic Organic Solvent, Absorption Behavior

\section{Introduction}

DNA denaturation and renaturation are important phenomena in a wide research area including biochemistry, analytical chemistry, and analytical science. DNA denaturation occurs when the hydrogen bonding between nucleotides is disrupted, and results in the separation of the strands. For example, denaturation of DNA due to high temperatures causes the disruption of the base pairs 
and the separation of the double-stranded helix into two single strands. Other than denaturation by heat, DNA can undergo denaturation through various chemical agents such as formamide, dimethyl sulfoxide, propylene glycol, and urea [1]. These chemical denaturing agents lower the melting temperature by competing for hydrogen bond donors and acceptors with the pre-existing nitrogenous base pairs. Some agents are even able to induce denaturation at room temperature. For instance, alkaline agents (e.g., $\mathrm{NaOH}$ ) have been shown to denature DNA by changing the $\mathrm{pH}$ and removing hydrogen-bond contributing protons [1]. Also, many researchers have reported denaturation of DNA in mixed solutions, such as water/ethylene glycol [2], water/ $\mathrm{NaCl} /$ hydrophilic solvents or compounds [3], water/glycerol [4], and water/alcohol [5]. However, as far as we know, nobody has examined denaturation of DNA through interaction between DNA and hydrophobic organic solvents, such as ethyl acetate, naturally because DNA molecules cannot contact directly to hydrophobic organic solvent molecules.

In addition, an area of partially separated DNA is known as the denaturation bubble [6] [7] [8] [9]; non-covalent interactions between antiparallel strands in DNA can be partially broken in order to open the double helix when biologically important mechanisms such as DNA replication, transcription, DNA repair or protein binding are set to occur. Currently, biophysical and biochemical research studies are being performed to more fully elucidate the thermodynamic details of the denaturation bubble [7].

In our previous paper [10], we reported that the peak shapes in the chromatograms of $\lambda$-DNA changed with a ternary water/hydrophilic/hydrophobic organic solvent mixed solution through the absorption detection at $260 \mathrm{~nm}$, but the reason remained unclear. In this study, DNA denaturation and the denaturation bubble were examined in a ternary water/hydrophilic/hydrophobic organic solvent solution using absorption spectroscopy, which was a challenge to know, for the first time, interaction between DNA molecules and hydrophobic organic solvent molecules. The hydrophobic organic solvent molecules in the ternary mixed solution could interact with DNA molecules in the solution to cause eccentric denaturation.

\section{Experimental}

\subsection{Reagents}

Water was purified with an Elix 3 UV (Millipore Co.). All reagents used were commercially available and of analytical grade. Acetonitrile, ethyl acetate, and $\lambda$-DNA $\left(0.35 \mu \mathrm{g} \cdot \mu \mathrm{L}^{-1}, M_{\mathrm{w}} 31,500,000,48,502 \mathrm{bp}\right.$, containing $10 \mathrm{mM}$ Tris- $\mathrm{HCl}$ ( $\mathrm{pH}$ 7.9) and $1 \mathrm{mM}$ EDTA) were purchased from Wako Pure Chemical Industries, Ltd. Plasmid (0.12 $\mu \mathrm{g} \cdot \mu \mathrm{L}^{-1}, 5446 \mathrm{bp}$, containing $10 \mathrm{mM}$ Tris- $\mathrm{HCl}(\mathrm{pH}$ 7.9) and $1 \mathrm{mM}$ EDTA) was replicated from pcDNA3 (Invitrogen Co.).

\subsection{Absorption Analysis and Electrophoresis}

Absorption analysis was carried out by an ultraviolet-visible spectrophotometer 
(JASCO Co., V-630). $\lambda$-DNA and plasmid original solutions were diluted with water, binary mixed solutions, and ternary mixed solutions to give fixed concentrations. Absorption spectra of $\lambda$-DNA and plasmid in the solutions were measured after every standing times. Absorbance at $260 \mathrm{~nm}$ in the spectra was examined in detail for DNA denaturation.

Agarose gel electrophoresis was performed using an electrophoresis system (Mupid-2Plus, Mupid. Com.) as follows. $15 \mu \mathrm{L}$ of the water/acetonitrile/ethyl acetate mixed solution (15:3:2, volume ratio) containing plasmid $\left(0.12 \mu \mathrm{g} \cdot \mu \mathrm{L}^{-1}\right)$, $5 \%$ glycerol, $0.09 \%$ SDS and $0.005 \%$ bromophenol blue was subjected to agarose gel electrophoresis. Plasmid was migrated in the gel containing $2.28 \mathrm{nM}$ ethidium bromide with $100 \mathrm{~V}$ for ca. $40 \mathrm{~min}$. After the migration, the gel was irradiated with ultraviolet rays to observe the separated plasmid bands.

\section{Results and Discussion}

\subsection{Denaturation of $\lambda$-DNA in Absorption Behavior}

Figure 1 shows the absorption spectrum of $\lambda$-DNA in the ternary water/acetonitrile/ethyl acetate solution. The component ratio was adopted based on a preliminary experiment concerning $\lambda$-DNA solubility with the mixed solution [10]. The absorbance gradually increased with increasing standing time up to $48 \mathrm{~h}$, while, generally speaking, DNA denaturation by heat occurs very quickly within several minutes and that by chemical agents also occurs at most in several hours [1]. There was quite difference in denaturation rate between the conventional methods and the present one. At the absorbance maximum of $260 \mathrm{~nm}$, the absorbance increased by a factor of 1.68 times from 0 to $48 \mathrm{~h}$ standing time. The change in absorbance of $\lambda$-DNA is due to change in structure from a double helix to a single helix, i.e., denaturation [11] [12] [13].

We also examined the absorbance of $\lambda$-DNA with the ternary mixed solution as well as with pure water and a binary water/acetonitrile (15:3, volume ratio) solution for $120 \mathrm{~h}$ standing time (Figure 2). All plots in the figure were average

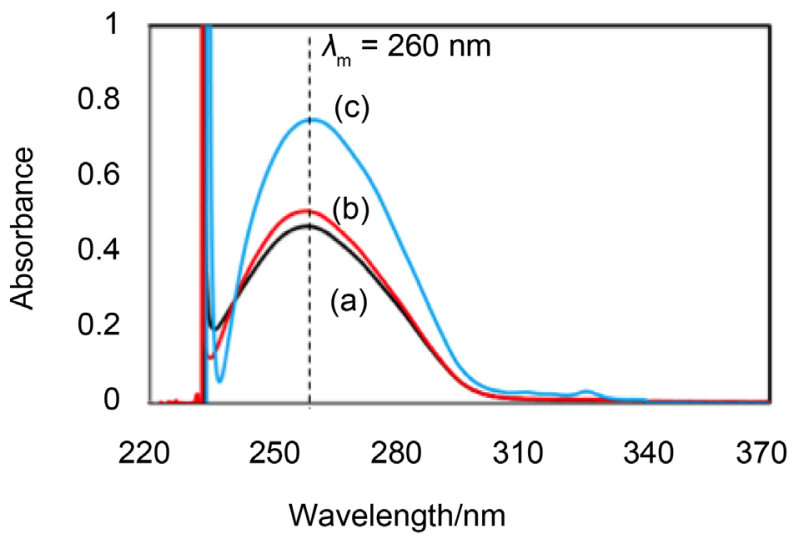

Figure 1. Absorption spectra of $\lambda$-DNA in the ternary mixed solution. Conditions: solution, water/acetonitrile/ethyl acetate (15:3:2, volume ratio); standing time, (a) 0, (b) 10, and (c) 48 $\mathrm{h}$; temperature, $23^{\circ} \mathrm{C}$; and $\lambda$-DNA concentration, $0.8 \mathrm{nM}$. 




Figure 2. Absorbance vs. time for $\lambda$-DNA in (a) pure water, (b) water/acetonitrile (15:3, volume ratio), and (c) water/acetonitrile/ethyl acetate (15:3:2, volume ratio). Relative absorbance on the vertical line is estimated based on the absorbance at $260 \mathrm{~nm}$ for the standing time of $0 \mathrm{~h}$. Conditions: temperature, $23^{\circ} \mathrm{C}$ and $\lambda$-DNA concentration, $0.8 \mathrm{nM}$.

values of 5 - 7 measurements. As shown in the figure, there was little change in the absorbance in both cases. The $\lambda$-DNA solution of the ternary mixed solution that was left for $48 \mathrm{~h}$ was diluted 5 times with water to obtain a component ratio of water/acetonitrile/ethyl acetate of 95:3:2, and then left for an additional $48 \mathrm{~h}$. The molar absorption coefficient did not change, maintaining a constant value of ca. $0.80 \mathrm{~L} \cdot \mathrm{cm}^{-1} \cdot \mathrm{nmol}^{-1}$ during the dilution. The denaturation of $\lambda$-DNA must be due to the presence of hydrophobic organic solvent, ethyl acetate, but the renaturation was not observed through the absorbance change under the present dilution treatment.

The increase in absorbance at $260 \mathrm{~nm}$ of $\lambda$-DNA in the water/acetonitrile/ethyl acetate (15:3:2, volume ratio) mixed solution was compared to those in other ternary mixed solutions with the same component ratios. We determined their relative absorbances by defining the absorbance at $260 \mathrm{~nm}$ of $\lambda$ DNA ( $0.8 \mathrm{nM})$ in water/acetonitrile (15:3, volume ratio) for $48 \mathrm{~h}$ standing to be 1.0. The values of relative absorbance for water/acetonitrile/ethyl acetate, water/acetonitrile/chloroform, and water/acetonitrile/hexane were 1.60, 1.07, and 1.15, respectively. Those of water/acetonitrile/ethyl acetate, water/methanol/ ethyl acetate, and water/2-propanal/ethyl acetate were 1.60, 1.20, and 1.35, respectively. There was no absorbance change for water/methanol and water/2propanal (15:3, volume ratio) mixed solutions. Thus, the hydrophobic organic solvent plays an important role in the denaturation that occurs with the ternary mixed solutions. The water/acetonitrile/ethyl acetate mixed solvent solution showed the largest change in absorbance at $260 \mathrm{~nm}$ of $\lambda$-DNA. Chemical and physical property of the ternary mixed solutions may cause other unique and interesting phenomena in DNA research area in future. 


\subsection{Denaturation of Plasmid in Absorbance Behavior}

Figure 3 shows the time dependence of the absorbance of the plasmid at $260 \mathrm{~nm}$ in pure water, water/acetonitrile (15:3, volume ratio), and water/acetonitrile/ ethyl acetate (15:3:2, volume ratio). All plots data in Figure 3 were average values of 5 - 7 measurements. The absorbance in the ternary mixed solution gradually increased with time until $120 \mathrm{~h}$. The absorbance at $260 \mathrm{~nm}$ increased by about 1.38 -fold from 0 to $120 \mathrm{~h}$ standing time. After that, there was no change in the absorbance for a total of $240 \mathrm{~h}$ standing time. The absorbance in the other solutions increased by less than 1.1 -fold. The denaturation of $\lambda$-DNA is nearly complete when the relative absorbance is 1.68 , but the plasmid is only partially denatured at 1.38 . This will be discussed in conjunction with the electrophoretic data mentioned below.

\subsection{Denaturation of Plasmid in Electrophoresis}

We examined the structure of the plasmid with agarose gel electrophoresis, but could not do that with $\lambda$-DNA because of its large molecular weight. Figure 4 shows the electrophoretic bands of DNA. The conditions are described in the figure caption. The lanes of (a)-(b) mainly comprised two bands: slow-migrating bands due to the open circular structure and fast-migrating bands due to the super-coiled one. In the order of (a) water, (b) water/acetonitrile (volume ratio, 15:3), and (c) water/acetonitrile/ethyl acetate (volume ratio, 15:3:2), the density of the slow-migrating bands increased and that of the fast-migrating ones decreased. In other words, the super-coiled structure changed to an open circular structure with acetonitrile and even more so with ethyl acetate.

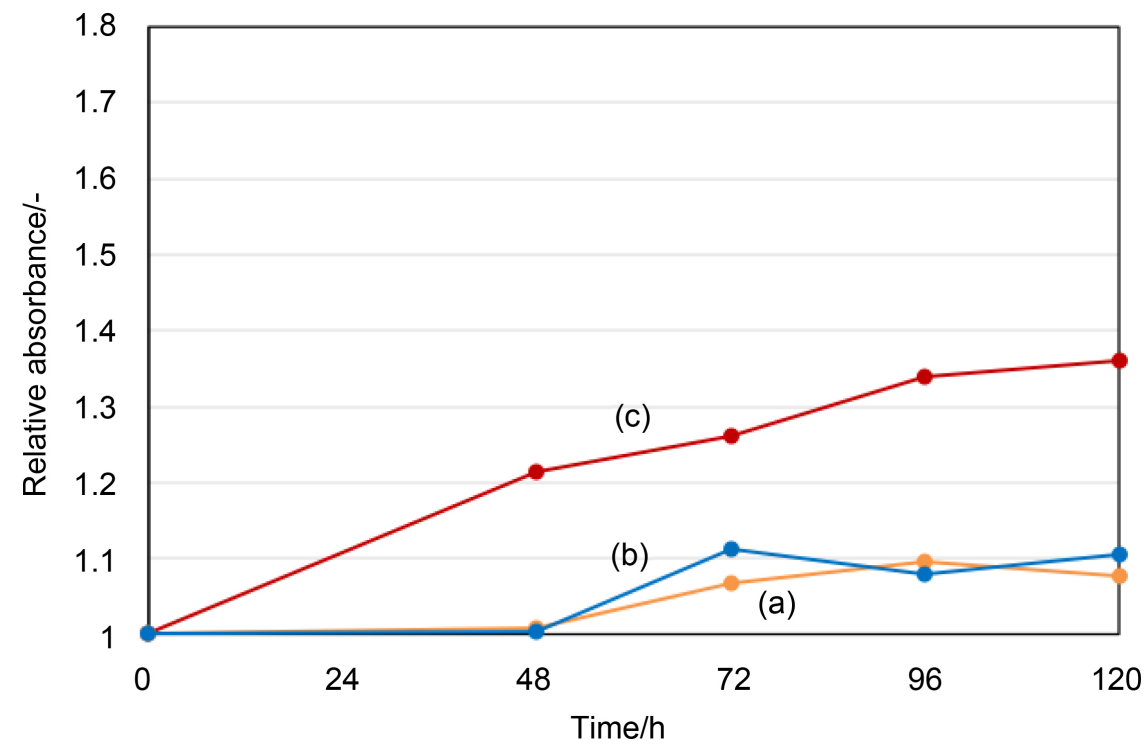

Figure 3. Absorbance vs. time for plasmid in (a) water, (b) water/acetonitrile (15:3, volume ratio), and (c) water/acetonitrile-ethyl acetate (15:3:2, volume ratio). Relative absorbance on the vertical line is estimated based on the absorbance at $260 \mathrm{~nm}$ for the standing time of $0 \mathrm{~h}$. Conditions: temperature, $30^{\circ} \mathrm{C}$ and plasmid concentration, 0.12 $\mu g \cdot \mu \mathrm{L}^{-1}$. 


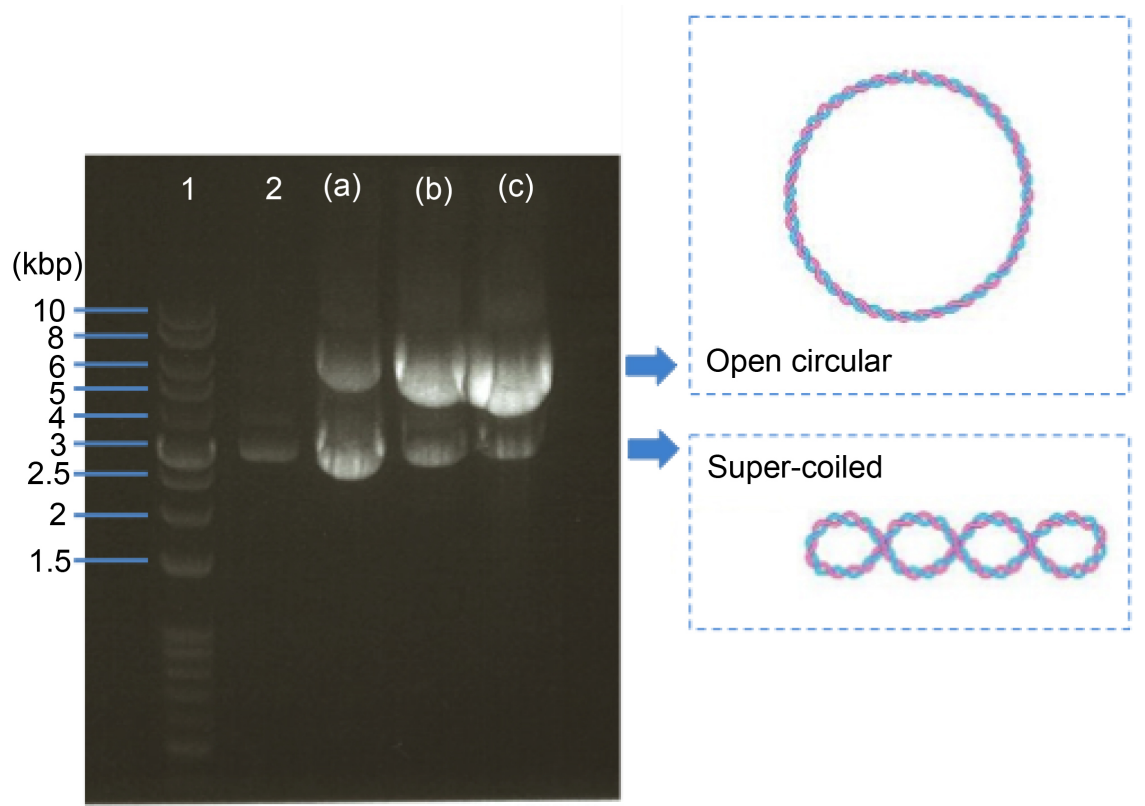

Figure 4. Electrophoretic bands of (1) DNA ladder and $5.5 \mathrm{nM}$ plasmid in Tris-EDTA solution as well as plasmid treated with (a) water, (b) water/acetonitrile (15:3, volume ratio), and (c) water/acetonitrile/ethyl acetate (15:3:2, volume ratio). Plasmid treatment conditions for (a)-(c): standing time, $72 \mathrm{~h}$; temperature, $30^{\circ} \mathrm{C}$; and plasmid concentration, $0.12 \mu \mathrm{g} \cdot \mu \mathrm{L}^{-1}$.

There was no evidence for the existence of a single-helix plasmid in the experiment; if a single-helix plasmid had existed, it would have migrated faster than the super-coiled one. However, as shown in Figure 3, we observed a 1.38-fold increase in the absorbance at $260 \mathrm{~nm}$ of the plasmid. This increase must be attributed to a denaturation bubble (partial change from double helix to single helix) [6] [7] in the ternary mixed solution.

\section{Conclusions}

Denaturation was examined for the first time in the ternary water/hydrophilic/ hydrophobic organic solvent mixed solution using $\lambda$-DNA and a plasmid as models. The structure of $\lambda$-DNA changed from a double helix to a single helix and the plasmid formed a denaturation bubble in the water/acetonitrile/ethyl acetate (15:3:2, volume ratio) mixed solution. The ternary mixed solution first enabled contact of a hydrophobic organic solvent (e.g., ethyl acetate) molecule to the double helix of DNA to cause denaturation in the solution. DNA in the ternary mixed solution showed specific slow-proceeding denaturation, although it was difficult to compare and discuss other reported data, because of no data concerning DNA denaturation in ternary mixed solutions. DNA denaturation is well known and widely applied in DNA-related research areas. However, DNA denaturation also includes unclear aspects even now. DNA denaturation with interaction of hydrophobic organic solvent molecules in the ternary mixed solution is interesting as a new type of procedure and may provide clues to further clarify this process. 


\section{Acknowledgements}

This work was supported by a Grant-in-Aid for Scientific Research (B) from the Ministry of Education, Culture, Sports, Science, and Technology, Japan (MEXT) (No. 17H03083).

\section{References}

[1] Wang, X., Lim, H.J. and Son, A. (2014) Characterization of Denaturation and Renaturation of DNA for DNA Hybridization. Environmental Health and Toxicology, 29, e2014007. https://doi.org/10.5620/eht.2014.29.e2014007

[2] Hickey, D.R. and Turner, D.H. (1985) Solvent Effects on the Stability of A7U7p. Biochemistry, 24, 2086-2094. https://doi.org/10.1021/bi00329a042

[3] Hammouda, B. and Worcester, D. (2006) The Denaturation Transition of DNA in Mixed Solvents. Biophysical Journal, 91, 2237-2242.

https://doi.org/10.1529/biophysj.106.083691

[4] Bonner, G. and Klibanov, A.M. (2000) Structural Stability of DNA in Nonaqueous Solvents. Biotechnology and Bioengineering, 68, 339-344. https://doi.org/10.1002/(SICI)1097-0290(20000505)68:3<339::AID-BIT12>3.0.CO;2 -O

[5] Hammouda, B. (2009) Insught into the Denaturation Transition of DNA. International Journal of Biological Macromolecules, 45, 532-534. https://doi.org/10.1016/j.ijbiomac.2009.09.002

[6] Sicard, F., Destainville, N. and Manghi, M. (2015) DNA Denaturation Bubbles: Free-Energy Landscape and Nucleation/Closure Rates. Journal of Chemical Physics, 142, 034903/1-034903/9. https://doi.org/10.1063/1.4905668

[7] Altan-Bonnet, G., Libchaber, A. and Krichevsky, O. (2003) Bubble Dynamics in Double-Stranded DNA. Physical Review Letters, 90, 138101/1-138101/4. https://doi.org/10.1103/PhysRevLett.90.138101

[8] Kuetche, V.K. (2016) Ab Initio Bubble-Driven Denaturation of Double-Stranded DNA: Self-Mechanical Theory. Journal of Theoretical Biology, 401, 15-29. https://doi.org/10.1016/j.jtbi.2016.04.026

[9] Chao, S., Fanjin, S., Meiling, Z., Pansong. Z., Yifan, W. and Cuiping, M. (2016) Triggered Isothermal PCR by Denaturation Bubble-Mediated Strand Exchange Amplification. Chemical Communications, 52, 11551-11554. https://doi.org/10.1039/C6CC05906F

[10] Nogami, T., Fujinaga, S., Jinno, N., Hashimoto, M. and Tsukagoshi, K. (2012) Elution Behavior of Lambda-DNA with Ternary Mixed Carrier Solvents in an OpenTubular Capillary under Laminar Flow Conditions. Analytical Sciences, 28, $617-$ 620. https://doi.org/10.2116/analsci.28.617

[11] Warner, R.C. (1957) Polynucleotides Synthesized by Polynucleotide Phosphorylase. III. Interaction and Ultraviolet Absorption. Journal of Biological Chemistry, 229, 711-724.

[12] Brahms, J., Michelson, A.M. and Van Holde, K.E. (1966) Adenylate Oligomers in Single- and Double-Strand Conformation. Journal of Molecular Biology, 15, $467-$ 488. https://doi.org/10.1016/S0022-2836(66)80122-5

[13] Blake, B.D. and Fresco, J.R. (1973) Polynucleotides. XI. Thermodynamics of (A)N.2(U)00 from the Dependence of TmN (Helix-Coil Transition Temperature) on Oligomer Length. Biopolymers, 12, 775-789.

https://doi.org/10.1002/bip.1973.360120407 
Submit or recommend next manuscript to SCIRP and we will provide best service for you:

Accepting pre-submission inquiries through Email, Facebook, LinkedIn, Twitter, etc. A wide selection of journals (inclusive of 9 subjects, more than 200 journals)

Providing 24-hour high-quality service

User-friendly online submission system

Fair and swift peer-review system

Efficient typesetting and proofreading procedure

Display of the result of downloads and visits, as well as the number of cited articles Maximum dissemination of your research work

Submit your manuscript at: http://papersubmission.scirp.org/

Or contact jasmi@scirp.org 